\title{
Front Matter: Volume 11243
}

, "Front Matter: Volume 11243," Proc. SPIE 11243, Imaging, Manipulation, and Analysis of Biomolecules, Cells, and Tissues XVIII, 1124301 (4 March 2020); doi: 10.1117/12.2566015

SPIE. Event: SPIE BiOS, 2020, San Francisco, California, United States 


\section{PROGRESS IN BIOMEDICAL OPTICS AND IMAGING}

\section{Imaging, Manipulation, and Analysis of Biomolecules, Cells, and Tissues XVIII}

Daniel L. Farkas

Attila Tarnok

Editors

3-6 February 2020

San Francisco, California, United States

Sponsored and Published by

SPIE 
The papers in this volume were part of the technical conference cited on the cover and title page. Papers were selected and subject to review by the editors and conference program committee. Some conference presentations may not be available for publication. Additional papers and presentation recordings may be available online in the SPIE Digital Library at SPIEDigitalLibrary.org.

The papers reflect the work and thoughts of the authors and are published herein as submitted. The publisher is not responsible for the validity of the information or for any outcomes resulting from reliance thereon.

Please use the following format to cite material from these proceedings:

Author(s), "Title of Paper," in Imaging, Manipulation, and Analysis of Biomolecules, Cells, and Tissues XVIII, edited by Daniel L. Farkas, Attila Tarnok, Proceedings of SPIE Vol. 11243 (SPIE, Bellingham, WA, 2020) Seven-digit Article CID Number.

ISSN: 1605-7422

ISSN: 2410-9045 (electronic)

ISBN: 9781510632493

ISBN: 9781510632509 (electronic)

Published by

SPIE

P.O. Box 10, Bellingham, Washington 98227-0010 USA

Telephone +1 3606763290 (Pacific Time) · Fax +1 3606471445

SPIE.org

Copyright (c) 2020, Society of Photo-Optical Instrumentation Engineers.

Copying of material in this book for internal or personal use, or for the internal or personal use of specific clients, beyond the fair use provisions granted by the U.S. Copyright Law is authorized by SPIE subject to payment of copying fees. The Transactional Reporting Service base fee for this volume is $\$ 21.00$ per article (or portion thereof), which should be paid directly to the Copyright Clearance Center (CCC), 222 Rosewood Drive, Danvers, MA 01923. Payment may also be made electronically through CCC Online at copyright.com. Other copying for republication, resale, advertising or promotion, or any form of systematic or multiple reproduction of any material in this book is prohibited except with permission in writing from the publisher. The CCC fee code is 1605$7422 / 20 / \$ 21.00$.

Printed in the United States of America by Curran Associates, Inc., under license from SPIE.

Publication of record for individual papers is online in the SPIE Digital Library.

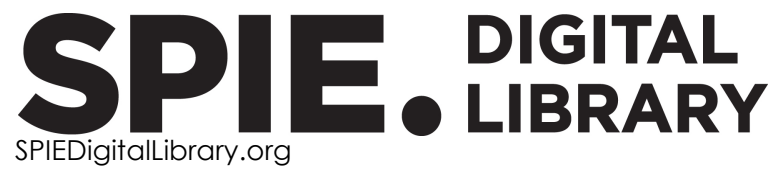

Paper Numbering: Proceedings of SPIE follow an e-First publication model. A unique citation identifier (CID) number is assigned to each article at the time of publication. Utilization of CIDs allows articles to be fully citable as soon as they are published online, and connects the same identifier to all online and print versions of the publication. SPIE uses a seven-digit CID article numbering system structured as follows:

- The first five digits correspond to the SPIE volume number.

- The last two digits indicate publication order within the volume using a Base 36 numbering system employing both numerals and letters. These two-number sets start with 00, 01, 02, 03, 04, $05,06,07,08,09,0 A, 0 B \ldots$ OZ, followed by 10-1Z, 20-2Z, etc. The CID Number appears on each page of the manuscript. 


\title{
Contents
}

\author{
$\checkmark \quad$ Authors \\ vii Conference Committee
}

\section{FUNCTIONAL IMAGING II}

$112430 \mathrm{Ol} \quad$ Estimation of melanin concentration, blood concentration, and oxygen saturation in skin tissue layers with different depths unaffected by shading [1 1243-18]

11243 OK Dual-color on-chip light sheet microscopy of drosophila embryos [11243-20]

BIOMEDICAL IMAGING USING A DMD OR OTHER MEMS ARRAY: JOINT SESSION WITH 11243 AND 11294

$11243 \mathrm{OL} \quad$ Spectral illumination system utilizing spherical reflection optics [11243-22]

\section{CYTOMICS II}

$112430 Q \quad$ Optimizing white blood cell contrast in graded-field capillaroscopy using capillary tissue phantoms [11243-27]

11243 OS Flow cytometry visualization and real-time processing with a CMOS SPAD array and highspeed hardware implementation algorithm [11243-29]

11243 OT Instance segmentation of immune cells in human lupus nephritis using deep learning: comparing performance on sample preparation and staining panels [11243-30]

\section{CYTOMICS III}

11243 OY Comparison of spectral FRET microscopy approaches for single-cell analysis [11243-35]

\section{SPECTRAL IMAGING I}

1124311 Towards an ultrathin multi-aperture microscope [11243-39] 
SPECTRAL IMAGING II

1124317 Deep UV microscopy of prostate cancer tissue [11243-45]

MONITORING AND REGENERATIVE MEDICINE I

11243 ID Probing metabolic alteration of differentiating induced pluripotent stem cells using label-free FLIM [11243-51]

FUNCTIONAL IMAGING III

$112431 \mathrm{P} \quad$ Lymph node micrometastases detection using paired-agent imaging protocol with biological tissue model [11243-12]

$112431 \mathrm{R} \quad$ Structural remodeling of fibrillar collagens in posterior tibial tendinopathy in three dimensional space identified using multiphoton and second harmonic generation imaging [1 1243-14]

\section{POSTER SESSION}

$112431 \mathrm{~T} \quad$ Indirect and direct pharmacokinetic parameter reconstruction in dynamic diffuse fluorescence tomography by adaptive extended Kalman filtering scheme [11243-60]

$112431 \mathrm{~W} \quad$ Enhancement of Xe-NMR signals at low magnetic field using optical pumping hyperpolarization [11243-63]

1124312 The development of a mechano-biological assessment of leukemia cells using optical tweezers [11243-66] 


\title{
Authors
}

Numbers in the index correspond to the last two digits of the seven-digit citation identifier (CID) article numbering system used in Proceedings of SPIE. The first five digits reflect the volume number. Base 36 numbering is employed for the last two digits and indicates the order of articles within the volume. Numbers start with 00, 01, 02, 03, 04, 05, 06, 07, 08, 09, OA, OB...0Z, followed by 10-12, 20-2Z, etc.

\author{
Abraham, Rebecca, OT \\ Abraham, Thomas, 1R \\ Ai, Junting, OT \\ Aluko, Justin, OS \\ Ameer-Beg, Simon M., OS \\ Annamdevula, Naga, OY \\ Artyuhov, A., 1D \\ Aydogan, Umur, $1 \mathrm{R}$ \\ Bassi, Andrea, OK \\ Beckert, E., 11 \\ Berlich, R., 11 \\ Bobrow, Taylor L., $\mathrm{OQ}$ \\ Bragheri, Francesca, OK \\ Brankov, Jovan G., 1 P \\ Brooks, Jamison, $1 \mathrm{Z}$ \\ Brost, Eric, $1 \mathrm{Z}$ \\ Browning, Craig, OL, OY \\ Carkaci-Salli, Nurgul, IR \\ Castriotta, Michele, OK \\ Cifu, Benjamin, ОT \\ Clark, Marcus R., OT \\ Damm, C., 11 \\ Dannberg, P., 11 \\ Danz, N., 11 \\ Dashinimaev, E., 1D \\ Deal, Joshua, OY \\ Durkee, Madeleine S., OT \\ Durr, Nicholas J., OQ \\ Elagin, V., 1D \\ Erdogan, Ahmet T., OS \\ Gao, Feng, $1 T$ \\ Giger, Maryellen L., OT \\ Green, Adam, 12 \\ Griswold, John Robert, OY \\ Gunn Mayes, Samantha, OL \\ Gyongy, Istvan, OS \\ Hattori, Mineyuki, IW \\ He, Yusheng, IP \\ Henderson, Robert K., OS \\ Höfer, B., 11 \\ Hui, Susanta, 12 \\ Hur, Soojung Claire, $0 Q$ \\ Igarashi, Takanori, Ol \\ Iuchi, Kaito, 0 I \\ Kalyan, Srivathsan, $O Q$ \\ Kashina, A., 1D \\ Kludze, Atsutse, 17 \\ Koob, K. Rebecca, IR \\ Kryukov, E., ID
}

Kumagai, Hiroshi, IW

Lall, Malvika, OY

Leavesley, Silas J., OL, OY

Li, Chengyue, IP

Li, Jiao, IT

Liarski, Vladimir M., OT

Liu, Han, $1 T$

Mai, Hanning, OS

Mattioli Della Rocca, Francesco, OS

Mayes, Samuel A., OL

McKay, Gregory N., OQ

Meleshina, A., ID

Memeo, Roberto, OK

Mescheryakova, N., ID

Nedbal, Jakub, OS

Nomura, Ikumi, OI

Odom, Aliyah, OY

Ojaghi, Ashkan, 17

Ojima, Nobutoshi, 0I

Osellame, Roberto, OK

Paiè, Petra, OK

Parker, Marina, OL, OY

Pleshinger, Donald John, OY

Poland, Simon P., OS

Reunov, D., 1D

Rich, Thomas C., OL, OY

Robles, Francisco E., 17

Rodimova, S., 1D

Sala, Federico, OK

Schacke, S., 11

Shi, Ke, $1 T$

Sibley, Adam, 0T

Soltani, Soheil, 17

Takeda, Shun, IW

Tayara, Alia, OY

Tichaver, Kenneth M., IP

Torres, Veronica C., IP

Treacy, Conor, OS

Tsumura, Norimichi, Ol

Vaccari, Thomas, OK

Vorotelyak, E., ID

Walker, Richard, OS

$\mathrm{XU}$, Xiaochun, IP

Zaage, B., 11

Zagaynova, E., ID

Zhang, Limin, IT

Zhang, Yanqi, IT

Zhao, Zhichao, $1 T$

Zhou, Zhongxing, $1 \mathrm{~T}$ 
Proc. of SPIE Vol. 11243 1124301-6

\section{Downloaded From: https://www.spiedigitallibrary.org/conference-proceedings-of-spie on 26 Apr 2023
Terms of Use: https://www.spiedigitallibrary.org/terms-of-use}




\section{Conference Committee}

Symposium Chairs

Jennifer K. Barton, The University of Arizona (United States)

Wolfgang Drexler, Medizinische Universität Wien (Austria)

Program Track Chairs

Ammasi Periasamy, University of Virginia (United States)

Daniel L. Farkas, University of Southern California (United States) and SMI (United States)

Conference Chairs

Daniel L. Farkas, University of Southern California (United States) and SMI (United States)

Attila Tarnok, Universität Leipzig (Germany)

Conference CoChair

James F. Leary, Purdue University (United States)

Conference Program Committee

Vadim Backman, Northwestern University (United States)

Christopher H. Contag, Michigan State University (United States)

Paul M. W. French, Imperial College London (United Kingdom)

Yuval Garini, Bar-llan University (Israel)

Sona Hosseini, Jet Propulsion Laboratory (United States)

Jae Youn Hwang, Daegu Gyeongbuk Institute of Science \&

Technology (Korea, Republic of)

Anna Khimchenko, Massachusetts General Hospital (United States)

Charles P. Lin, Wellman Center for Photomedicine (United States)

Sacha Loiseau, Mauna Kea Technologies (France)

Ramesh Raghavachari, U.S. Food and Drug Administration

(United States)

Sebastian Wachsmann-Hogiu, McGill University (Canada)

Session Chairs

1 Translational Biophotonics: 30th Anniversary I

Daniel L. Farkas, University of Southern California (United States) and SMI (United States) 
2 Functional Imaging I

Daniel L. Farkas, University of Southern California (United States) and SMI (United States)

4 Functional Imaging II

Daniel L. Farkas, University of Southern California (United States) and SMI (United States)

5 Biomedical Imaging using a DMD or Other MEMS Array: Joint Session with 11243 and 11294

Karel J. Zuzak, University of Texas Southwestern Medical Center (United States) and The Laboratory of Biomedical Imaging and Engineering, LBI-51, LLC (United States)

Bin Yang, Duquesne University (United States)

6 Biomedical Fabrication using a DMD or Other MEMS Array: Joint Session with 11243 and 11294

Jorge Moguel, Digital Light Innovations (United States)

Attila Tárnok, Universität Leipzig (Germany)

7 Cytomics II

Attila Tárnok, Universität Leipzig (Germany)

8 Cytomics III

Attila Tárnok, Universität Leipzig (Germany)

9 Spectral Imaging I

Attila Tárnok, Universität Leipzig (Germany)

10 Spectral Imaging II

Irene Georgakoudi, Tufts University (United States)

11 Monitoring and Regenerative Medicine I

Attila Tárnok, Universität Leipzig (Germany)

12 Monitoring and Regenerative Medicine II

Attila Tárnok, Universität Leipzig (Germany)

13 Bioinformatics and Analysis

Attila Tárnok, Universität Leipzig (Germany)

14 Functional Imaging III

Daniel L. Farkas, University of Southern California (United States) and SMI (United States) 